\title{
A Critical Review and Future Directions for Research: Personality and Social Entrepreneurial Success
}

\author{
Sahni $S P^{1}$, Sharma $S^{2^{*}}$ and Aggarwal $S^{3}$ \\ ${ }^{1}$ Executive Director, Jindal Institute of Behavioural Sciences and Member of Governing Body, O.P. Jindal \\ Global University, India \\ ${ }^{2}$ Assistant Professor, Jindal Institute of Behavioural Sciences, O.P. Jindal Global University, India \\ ${ }^{3}$ MBA Student, O.P. Jindal Global University, India
}

*Corresponding author: Shilpi Sharma, PhD, CPsychol, Assistant Professor, Jindal Global Law School, O.P. Jindal Global University, Sonepat Narela Road, 131001 India, E-mail: shilpi@jgu.edu.in

\begin{abstract}
Probably millions of people across the world dream of starting their own business, a fraction of them may gather the courage and resources to pursue their ambitions, and still, even a smaller fraction of those may persevere through the challenges and inevitable disappointments, entrepreneurial process may present. FInally, a very small number of entrepreneurs succeed in achieving their objectives. What determines the difference in behaviours and attitudes of these individuals? Why some never seek available opportunities, while other dig out hidden potential in coal and convert it to gold? Why would some entrepreneurs give up half way in between; while others would overcome every obstacle, they may find in the way of achieving success. In addition to personality, which remains the largest area of psychological research in social entrepreneurship; recent research has also cited the significance of a personality attribute, matched to the specific tasks, each stage of an entrepreneurship might require, as a significant predictor of performance. In the current paper, we argue that just the trait approach to understanding underpinning personality dimensions to entrepreneurship is not sufficient. An understanding of the dynamic psychological functions and attitudes, as delineated by Jung will facilitate understanding of the strengths and weaknesses a potential entrepreneur may exhibit in any given situation.
\end{abstract}

\section{Introduction}

A dramatic growth of self-employment has sparked significant interest of social scientists and political authorities in the field of entrepreneurship [1-3]. World economy has recently been heavily relying on the revenue generated by entrepreneurial development
[4], as over 3.5 million new businesses are initiated each year in the United States; while Fortune 500 was reported to lose over 500 million jobs [5].

Conceptual and empirical predilections have been applied by academics as well as management experts [6] through hundreds of research studies, in an attempt to disentangle the complex, multi-dimensional process of entrepreneurship [7]. This is only a recent development as until 1980s, entrepreneurship was a peripheral perusal of individuals seeking their own source of income [8]; and the term 'social entrepreneur' was not coined until the year 1984 [9]. Despite numerous attempts over past two decades, there still exists a degree of scepticism in outlining the rudimentary elements for the concept of social entrepreneurship [10-13].

The number of self-employed enterprises is constantly rising, and they are at the peak of their success, recognition and glory than ever before in the human history. It has been widely acknowledged that only certain individuals with distinctive personality types may initiate and succeed in entrepreneurship initiatives [14]. Being able to predict the likelihood of someone succeeding in an entrepreneurship venture is of high significance to funding agencies as they receive millions of applications every year from potential entrepreneurs. They must ensure that their limited funding goes into the right hands and that they get some returns on their investment. Personality screening is thus of high relevance to the field of entrepreneurship. The key 
issue in entrepreneurship research is of identifying a definite or at least a predictable set of personality traits underpinning entrepreneurship success as that is required by the screening procedures of the funding agencies.

\section{Origins of the Term Entrepreneur and its Defi- nition}

The origin of the word entrepreneur is the French word 'Enterprendre' which was translated in English word 'entrepreneur' by John Stewart Mill [15]. Webster's dictionary defines an entrepreneur as "one who organizes, manages, and assumes the risks of a business and enterprise. Entrepreneurship is also defined as "the process of creating something new with value by devoting the necessary time and effort, assuming the accompanying financial, psychic and social risks, time and effort; as well as receiving the resulting rewards of monetary and personal satisfaction; and independence".

An elementary definition of social entrepreneurship can be argued to be: people who engages in entrepreneurial activities to resolve social issues [9,11,16-20]. This is however, misleading and an incomplete portrayal of social entrepreneurs as there is no mention of their underpinning psychological attributes, behaviours and personality [21]; and is quite idealistic [9,11,18,19]. In depth analysis of various definitions postulated by social scientists over a decade reveal commonalities:

1. Some theorists have adopted an idealistic stance, thereby restricting social entrepreneurial activities to social value creation without any monetary profit. In reality, however a more balanced approach is found to be practical and sustainable $[5,20,22]$.

2. Psychological attributes such as risk taking, motivation and creativity are of paramount significance in determining the success of any entrepreneurial venture [23].

3. A close examination of the definitions also reveals a relevance of considering variant personality traits for different stages of the entrepreneurial process; such as greater risk taking may be required during the initial stages of seeking an opportunity, while a higher degree of motivation and creativity may become necessary for execution of the ideas stage.

Social and Commercial Entrepreneurs: A Discussion on Differences and Similarities

The academic interest in social entrepreneurship is relatively more recent than the entrepreneurial research [16,20,24-27]. However, both groups work towards achieving similar aims of exploiting opportunities, creating new markets and enhancing productivity, thus benefitting the society [11,28-30]. Nevertheless, it is equally important to acknowledge that the key distinguishing feature between commercial and social entrepreneurs lies in their personal motives and value propositions. Primary motives of social entrepreneurs are public welfare and social justice [20,31-33], while commercial entrepreneurs are focused more on personal monetary profit [29]. Target customer groups for a commercial entrepreneur are the people who hold the inclination as well as resources to invest in their innovations; on the other hand, social entrepreneurs target socially neglected, disadvantaged and downtrodden sectors of the population. This distinction creates two very different metrics for assessing success of commercial vs. social entrepreneurship. Personal gains for the entrepreneur as well as the stakeholders would be the intended outcome for a commercial entrepreneurship but an observable, positive impact in the lives of targeted social group would be essential for a social entrepreneurship to be successful $[11,29,32]$.

Social entrepreneurs are essentially like commercial entrepreneurs in terms of their ability and initiative to locate, identify and pursue a new business opportunity; however, a major distinction lies in the goals and intentions of the two groups. Social entrepreneurs aim to resolve a social problem from the outset and may even share a proportion of their monetary profit with the disadvantaged group [16,18,19,34-36]. Commercial entrepreneurs, on the other hand, intend to make money for personal gains, from day one! There is nothing ethically or legally wrong with the latter group, but social entrepreneurs just own a different set of priorities [37,38].

Classic or social, both groups of entrepreneurs are known to exhibit a distinct set of psychological attributes that allows them to detect a relevant business niche area, generate adequate sources of funding, develop and offer exciting products and services that may satisfy some needs of the targeted customer group. The overarching focus on social value creation of the social entrepreneur group allows them a greater degree of freedom in offering services that may not seem to be highly profitable in the first instance but guarantees satisfaction of certain needs [11,39].

The important question to consider here is whether such differences require a different set of psychological attributes? Perhaps not. Comparing what we know about skill sets needed by commercial and social entrepreneurs, it seems that a lot of skills are similar at first glance. Tracey and Phillips [40] noted that "social entrepreneurs need all the same skills and expertise as more traditional entrepreneurs when they build their businesses" (p. 268). In accordance with empirical research results, social scientists and economists and even politicians unanimously agree for the presence of certain, distinguishing personality traits [41] amongst the group of entrepreneurs [42,43] and social entrepreneurs [44,45], alike.

Despite such overwhelming evidence for the significance of personality traits in determining entrepre- 
neurial actions, other studies have still reported a small degree of explanatory power and predictive validity of individual personality as a variable in entrepreneurship research $[46,47]$. In a meta-analysis conducted by Rauch and Frese [48], a significant relationship was found between personality traits and business tasks at various stages of running an enterprise; and this association had a significant impact on the business outcome. So, personality traits were found to be important, only when they are matched to a particular business task, such as seeking funding, hiring manpower, or execution of a plan. Generic personality traits had little significance to the overall business outcome. We argue that it is a combination of psychological attributes that may form an individual's personality style, which is significant in determining entrepreneurial actions and efficiency, not just single traits [49]. Furthermore, recent findings also indicated that underpinning psychological attributes may vary for determining efficiency at different stages of an entrepreneurial process [50].

\section{Relevance of Personality Research in Entre- preneurship Literature}

Personality as a topic of study interests several disciplines and it is considered multi-faceted in nature. A variety of overlapping definitions have therefore been proposed to understand this phenomenon. Personality traits are defined as "enduring patterns of perceiving, relating to, and thinking about the environment and oneself that are exhibited in a wide range of social and personal contexts" [51]. Gordon Allport was one of the proponents in the personality research who argued it to be a dynamic integration of psychological systems inherent and unique to an individual's behaviours and adaptation to their environment [52]. Burger [53] emphasised on the interpersonal nature of a person's personality. Mount, et al. [54] argued personality to be determinant of an individual's emotions, cognitions and behaviours; thus, determining their unique identity.

Despite the current, universal agreement amongst scientists on the unique personality and psychological attributes of entrepreneurs and social entrepreneurs, alike [55], literature lacks consensus on the specific characteristics that may determine an entrepreneurs' actions [56]. During 1980s, majority of publications either denied or argued for an insignificant contribution of personality attributes in determining entrepreneurial success [57]. It was through studies comparing employed managers and self-employed entrepreneurs that formidable nature of personality research was noted $[47,58,59]$.

Specific personality dimensions of risk taking, motivation, locus of control, creativity, assertiveness, the need for achievement, innovation, independence, risktaking propensity, Type-A behavior, and tolerance for ambiguity and initiative are some of the commonly and consistently found personality dimensions in groups of social entrepreneurs [48,60-68]. A deeper examination of the definitions would also indicate the presence of these underpinning psychological attributes. For example, the definition by Tan [69] explicitly states risk taking and innovation as a part of the entrepreneurial profile. The definition by Ashoka [70], Mort, et al. [37] and Peredo and McClean [71] discusses ambition and persistence as important attributes, which requires motivation and internal locus of control. Furthermore, 'offering new ideas' bit of this definition would indicate creative side of entrepreneurs. Mair And Marti [11] also postulates creativity and motivational aspects of entrepreneurship by stating innovation and change making in their definitions.

Another popular stream of research in the field of personality analysis of entrepreneurs relates to the big five personality traits [55]. The big five personality traits of neuroticism, extraversion, conscientiousness, openness and agreeableness have been known to be associated with commercial entrepreneurship [42,43] and social entrepreneurship [44,45].

\section{Relevance of Personality Research in Social Entrepreneurship}

Use of personality dimensions in screening and recruitment of individuals for specific roles was initiated by Cattell in 1946 who identified 16 distinct personality factors that may determine an individual's behaviours and performance in a role. Cattell's 16 factors are still routinely used in the recruitment and performance development sectors by big organizations; as such personality traits are known to be predictive of an individual's performance. However, for some, 16 factors were just too much information to deal with for a lay person, so a condensed version of Big five personality traits was proposed by Norman in 1963. Big five personality factors of agreeableness, conscientiousness, extraversion, neuroticism, and openness to experience were tested and re-tested and empirically confirmed to be associated with entrepreneurial personality by rigorous research studies [72-74].

In essence, the role of entrepreneurs. Involves selling of their ideas, products or services to the potential funders as well as customers, which requires extraversion $[73,75]$. Entrepreneurship also involves adoption to change [76] and exhibition of novel approaches to creating new business strategies, products or services and solving problems [73]. These traits are indicative of the openness to change dimension of the Big five personality model [77].

Furthermore, entrepreneurs are known to be highly self-assured and self-confident about their ability to induce change or innovate for the benefit of the larger society or economy [78], which makes them score low on the tests of neuroticism $[79,80]$. Possession of a high motivation to achieve goals and strive for excellence 
in all their initiatives is known to be associated with conscientiousness, a trait and which entrepreneurs score really high $[81,82]$. For the last dimension of agreeableness on the big five personality model, low scores are generally preferred for entrepreneurs as that gives them the much-needed competitive attitude [73].

\section{Extraversion}

As discussed in Jung's typology, extraversion implies 'outward focused'. Extravert people are known to enjoy social settings and frequently engage in meet and greet with other people. They are known to be highly talkative, cheerful and self-assured, enabling them to initiate and sustain conversations with other people [83]. Extraversion is about finding the right amounts of passion and enthusiasm to get into meaningful, two-way conversations with people and being able to effectively suppress the expression of socially inappropriate, overwhelming achievements, ambitions and impulses [84]. Such competencies allow them to develop a good social network [85]. Introvert people, on the other hand, are 'inward oriented', they avoid social contact, unless it is absolutely necessary. Even while interacting with other individuals, introverts tend to be reserved, quiet, inhibited and hesitant in expressing ideas that are not fully developed/validated, because they fear being judged or negatively evaluated [86]. Extraversion is at the core of a social/classic entrepreneurial initiative as they are required to create and sustain social networks, hire people and establish strongly productive teams, stay in regular touch with other stakeholders, such as sponsors and customers; as well as engage in other activities such as sales and marketing, which may require high levels of social skills [73].

\section{Neuroticism}

The tendency to get anxious, upset, irritable and insecure by small changes in the environment is known as neuroticism. Neurotic people usually experience a greater degree of negative emotional states such as guilt, anger, hostility, depression, fear etc. Excessive negativity may lead to the development of a dubious irrationality in their thoughts and behaviour. They tend to be mistrusting, often impulsive and fail to negotiate their ways in conflicting situations [87]. However, such a personality can sometimes be exceptionally candid about other peoples' strengths and weaknesses, thus providing a valuable insight and sparking an honest stream of conversations that may lead to productive and creative meetings [88]. On the other hand, people with low neuroticism, tend to be calm, composed, selfconfident and relaxed in the face of stressful situations [73]. In reality, a balance between the two extremes of this personality type have been shown to most beneficial for a person's performance in a job [89].

\section{Conscientiousness}

The ability to organize, plan, persist and diligently complete all tasks within deadlines is referred to as conscientiousness. Highly conscientious people are usually hard-working, dependable, zealous, enterprising, and determined [73]. Another strength exhibited by people with high conscientiousness is their ability to stay motivated, excel and accomplish in high-demanding, unstructured tasks $[89,90]$. All these traits are central to ensuring success in entrepreneurial life and will ensure their survival during the most challenging phases of their business [91]. At the same individuals with high conscientiousness are also known to be significantly moral and uphold ethical values at all the times, thereby gaining the trust of those around them [92]. This quality makes them even more eligible for the role of a social entrepreneur. Most screening tests used for employment recruitment would value candidates scoring high on this dimension.

\section{Openness to experience}

In the entrepreneurship context, adaptability and openness to new experiences have been cited as important characteristics because an entrepreneurship culture would inevitably encourage frequent and constant change [93]. People who score high on the measures of openness to experience are often unconventional, flexible, adaptable and broad minded. While, the idea of a change may cause panic in regular population, an aspiring entrepreneur must exhibit a natural appeal for embracing change as they set out on this journey [94]. The extent to which an entrepreneur is able to identify an opportunity in uncertainty and is willing to venture into the unknown has been shown to be associated with entrepreneurial performance [95]. People who are active, imaginative, curious, exhibit a preference for variety and behold aesthetic sensitivity tend to be broad-minded, also known as open to new experiences. Open people also tend to be reflective, unconventional, independent and easy-going [92,96]. Openness allows them to embrace and absorb new experiences willingly and develop a wide perspective. They are often curious minded, seeking to explore new ideas and are therefore competent at 'cross-fertilization of ideas'. Any entrepreneurship begins by identification of an opportunity that may match their vision for 'change in global economy' $[29,97]$. Openness dimension of Big 5 traits is associated with intellectual curiosity, creativity, imagination and a strong liking for variety. This process requires an entrepreneur to be really 'sharp' and 'alert' to the target environment. Openness is also closely associated with an individual's risk-taking propensity and ability; and that is a fundamental requirement for being successful as an entrepreneur.

\section{Agreeableness}

Pro-social behaviours, friendliness, caring, compassionate, gentle, soft-spoken, cooperative, all these traits are the constituents of agreeable personality dimension, which is known to help them develop positive in- 
ter-personal relationships [83]. Highly agreeable people want to stay in consensus and 'be with the majority', all the time, thus avoid confrontations and conflict. Such an attitude may get them to be liked and accepted by the majority, but they lack the competitive stride and fail to get enough credit for their hard work and contributions [98]. Highly agreeable people are thus bad negotiators and can rarely persuade or manipulate anyone into doing something that might serve the purpose of self-gain and self-protection [73]. On the other hand, people scoring low on agreeable dimension are known to be selfish, manipulative, but at the same time competitive and ruthless in working towards their goals, which is required for succeeding in entrepreneurial ventures [92].

The big five personality traits are thus, relevant and useful in determining the potential of an individual at excelling in an entrepreneurship. Each dimension of the big five trait model acts like a psychological pillar to the entrepreneurship dream an individual might have. However, it might not be the sufficient perspective to account for all the complexities involved in setting up and making an enterprise successful.

\section{Trait vs. Type Approach}

The big five personality theory postulated that a degree of variation will be noted in their presentation in an individual's personality. Traits are argued to be part of a continuum; and a person may not always be extravert or neurotic; they may behave on the opposite end of a gradient leading from neuroticism to emotional stability at other times, which will also reflect in their behaviour and attitude. There is thus a degree of uncertainty in determining the precise personality traits of a successful social entrepreneur. There is no doubt that a constellation of personality traits determines the actions and effectiveness of those actions in social entrepreneurship. It is therefore relevant to direct our discussion to another perspective of type theories in personality research, which advocates for the presence of discrete, more stable personality types that may be predictive of an individual's behaviours in any given situation. In this context, it is relevant to quote Walter Mischel from 1968, who had argued that "with the possible exception of intelligence, highly generalized behavioral consistencies have not been demonstrated, and the concept of personality traits as broad predispositions is thus untenable". Leaving aside the stupendous stream of debate this comment had sparked amongst personality researchers, we are interested in drawing attention to the fact that just trait theories may not be sufficient to understand the underpinning psychological attributes of entrepreneurs. Trait theory may as well hold a relevance to personality research in entrepreneurship as different positions on a trait continuum facilitates a deeper understanding of individual motivations in response to the differing environmental situations. But, a trait approach will always extend infinite opportunities on a continuum and it will be impossible to determine the potential of individuals in running their own enterprise. We should therefore not turn our backs to the other fascinating and relevant stream of explanation of type theories.

One may argue that type theories were discarded to be a reliable explanation for personality during 1980s and that it is considered 'outdated' by some in current times. But it is equally well documented that despite inundated findings on personality research in the field of entrepreneurship, no conclusive theories could be founded; partly because of variation in the types of traits entrepreneurs present across different studies. This variation is not attributable to a flaw in any research study's design, it is due to the fact that a combination of several traits is responsible for entrepreneurial actions. Successful entrepreneurs also very well display discrete, stable characteristics over time, because of the consistency in the nature of challenges they are confronted with during various stages of an enterprise creation. It is comparable to an intelligence test. A specific set of skills are required to accurately complete the complexities inherent in an IQ test and that doesn't change across individuals or situations. Similarly, entrepreneurship is a complex process that requires specialized skill sets and the inherent challenges an entrepreneurship process offers are predictable and consistent across situations. There are certain prerequisites for successfully establishing and running one's own business; thus, specific personality types are indeed better oriented to fulfill those expectations, an enterprise creation beholds. Such a typology will not limit individuals into pre-formed categories but will provide the much-needed consistency and predictability to entrepreneurship research.

For example, a personality type, authoritarianism, first proposed by Gordon Allport in the year 1954, in his book titled 'The Nature of Prejudice', was widely applauded and internationally recognized for gaining insights into the reasons why so many people sympathized with the inhumane actions of Hitler during World War II. Same personality type was recently found to be one of the most significant predictors of American voters' preference for Donald Trump during US presidential elections [99]. Universal personality types are therefore relevant.

\section{Type Theory: Carl Jung's Model of Personality}

One of the predecessors of type theories was Carl Jung who proposed 16 distinct personality types based on four functions and two attitudes. Jung's theory offers the balance between trait vs. type stability debate as it acknowledges the fact that an individual's behaviours and choices are a result of their inherent predispositions with environmental circumstances. Human psychology is far too complex to restrict them into discrete categories. So, neither trait nor type theories provide a sufficient 
theoretical stance to fully appreciate the manner in which an individual's psychological attributes, not a type or trait, but characteristics determine their actions. According to Jung, personality attitudes of extroversion vs. introversion; and psychological functions of thinking, sensation, judging, perceiving, intuition and feeling, are of relevance in this context.

Attitudes in Jung's theory referred to the direction in which their energies are directed and drawn from. For an extravert, sources of stimulation are mostly external, they derive motivation and pleasure from interacting with the world; while introverts are inward directed and prefer to be in isolation, whenever possible. Functions were proposed to be cognitive styles, modes of orientation, the manner in which an individual process the information around them. They could either be rational by judging or irrational by perceiving. Judging function consists of sensation and thinking elements, which signify a reliance on concrete information received from the environment and cognitive processing of facts, respectively. On the other hand, perceiving function is characterized by intuition and feeling elements functions would rely on imaginative thinking, emotional biases and intuition, which is a sort of gut feeling to guide one's behaviour. Jung argued that functions or attitudes cannot occur in isolation to each other; they must work together to produce unique constellations of psychological characteristics that may be suggestive of the inherent complexities of their behaviours, actions and choices [100].

Another interesting component of Jung's theory was a discussion of dominant and inferior attitudes and functions. It was argued that genetically, individuals exhibit a tendency to process the information in specific ways. So, some individuals may be predisposed to act in extroverted ways and may tend to be more rational in most situations. This description helps understand why certain individuals are more likely to initiate and succeed in setting up and running an enterprise than others who might fret by the thought of it. Some of us just have it in us! It is a matter of screening and identifying who might have what it takes to be a successful entrepreneur [100].

Entrepreneurs are confronted with uncertain situations all the time and yet they are expected to take important decisions that may determine the fall or rise of the entire enterprise they are dreaming to build. It is not always possible for entrepreneurs to act rational as, sometimes, due to the novelty of their business idea, there is no means for collecting concrete information about the anticipated outcomes [101,102]. Entrepreneurs' decisions may partly be based on rational logic for issues such as, shelf life of the tangible resources, competition analysis, amounts of affordable losses and partly on their personal, subjective judgment about issues such as, the degree of trust they can place in the investors and other stakeholders and expected returns from their investments [103-109].

Another difficulty in identifying underpinning psychological attributes of successful entrepreneurs is that it is a complex, multi-staged process and each stage requires a different set of psychological characteristics. The key to understanding psychological predispositions of successful entrepreneurs is to embrace the idea that no one personality trait or style can make an individual cruise through all the complexities, an entrepreneurship presents. It is about understanding their natural preferences for behaviour and cognitions in specific contexts. So, some individuals may be a good fit for starting an enterprise, but they may not survive the challenges presented by the subsequent stages of an entrepreneurship process. Molino, et al. [110] posited a bottleneck model of entrepreneurship, wherein, many individuals may initiate an entrepreneurship idea, but in the end only some will make it to a successful, sustainable enterprise.

In the last few years, a number of publications have outlined the stages of an entrepreneurial process [111] with some degree of variation; the main steps towards establishing an independent enterprise are: conception of an idea, market research, testing the waters, gathering resources, marketing, launch and process evaluation [112].

It can be argued with confidence that of the two Jungian attitudes, extraversion is the favoured dimension for entrepreneurial success; but a degree of variation and balancing may be required between the four different functions. Some situations may require intuition-based decision making that would facilitate the essential risk taking, setting up of a new enterprise requires; while other situations, such as market appraisal and process evaluation would benefit from a careful, concrete, evidence-based business strategy. Decisions based on rational, cognitive processing of certain information are just as important as the ones grounded in empathy and the desire to maintain meaningful interactions with stakeholders.

Some researchers had argued for a 'jack of all trades' theory of entrepreneurship, suggesting that a successful entrepreneur is more like a solopreneur and must exhibit all the skills and talents a trade might require [113]. In reality, it may not be possible and for this very reason, most entrepreneurs would go on to hire people to help them take their business forward. However, a certain degree of adaptability is important across different stages of an entrepreneurship as the nature of tasks and the required skills would almost, always vary. This variation may be predictable, but the exact personality that may succeed in entrepreneurship is not. Jung's personality theory is therefore relevant in this context as it discusses an individual's psychological functions and attitudes, not stable traits. Functions and 
attitudes, as outlined by Jung, are individual tendencies to behave in a particular manner, which interacts with the environmental conditions to create unique outcomes across different situations.

\section{Conclusion}

An in-depth analysis of relevant research studies led to a conclusion that there may not be significant differences between social and commercial entrepreneurs for investigating personality dimensions underpinning their success. There is however a need to understand the two distinct kinds of contributions of personality research to the entrepreneurship literature. One in a way that suggests stable, fixed traits underpinning behaviours and actions of entrepreneurs; which may be referred to as the founding pillars of the entrepreneurship concept. Second, that there may be dynamic personality types, which could be understood by either Jung's theory of any other theory that may help understand the dynamic interactions between an individual's psychological attributes and the specific requirements of the distinct stages of an entrepreneurship process, in determining the outcome of that business initiative.

\section{References}

1. Alba A (1994) Self-employment in the midst of unemployment: The case of Spain and the United States. Applied Economics 26: 189-204.

2. Chay YW (1993) Social support, individual differences and well-being: A study of small business entrepreneurs and employees. Journal of Occupational and Organizational Psychology 66: 285-302.

3. Stevenson $\mathrm{HH}$ (1989) A perspective on entrepreneurship. In: Kao J, Entrepreneurship, creativity and organization. Prentice Hall International Editions, Englewood Cliffs, New Jersey, USA.

4. TimmonsJA(1999)NewVenture Creation: Entrepreneurship for the 21st Century. Irwin/McGraw-Hill, London, UK.

5. Wronka-Pośpiech M, Frączkiewicz-Wronka A, Dobrowolska $M(2018)$ Predicting managerial success in the case of polish social enterprises-personality perspective. In: Proceedings IFKAD 2017. St. Petersburg, Russia, 1689-1703.

6. Witkamp MJ, Royakkers LM, Raven RP (2011) From cowboys to diplomats: Challenges for social entrepreneurship in The Netherlands. Voluntas 22: 283-310.

7. Baum JR, Locke EA, Smith KG (2001) A multidimensional model of venture growth. Academy of Management Journal 44: 202-302.

8. Defourny J, Nyssens M (2013) Social co-operatives: When social enterprises meet the co-operative tradition. Journal of Entrepreneurial and Organizational Diversity 2: 11-33.

9. Cukier W, Trenholm S, Carl D, Gekas G (2011) Social entrepreneurship: A content analysis. Journal of Strategic Innovation and Sustainability 7: 99-119.

10. Dacin MT, Dacin PA (2011) Social entrepreneurship: A critique and future directions. Organization Science 22: 1203-1213.

11. Mair J, Martí I (2006) Social entrepreneurship research: A source of explanation, prediction, and delight. Journal of
World Business 41: 36-44.

12. Weerawardena J, Sullivan G (2006) Investigating social entrepreneurship: A multidimensional model. Journal of World Business 41: 21-35.

13. Zahra SA, Rawhouser HN, Bhawe N, Neubaum DO, Hayton JC (2008) Globalization of social entrepreneurship opportunities. Strategic Entrepreneurship Journal 2: 117131.

14. Littunen H (2000) Entrepreneurship and characteristics of the entrepreneurial personality. International Journal of Entrepreneurial Behavior and Research 6: 295-310.

15. Allah AM, Nakhaei H (2011) Entrepreneurship and risk-taking. International Conference on E-business, Management and Economics 25: 77-79.

16. Austin J, Stevenson H, Wei-Skillern J (2006) Social and commercial entrepreneurship: Same, different, or both? Entrepreneurship Theory and Practice 30: 1-22.

17. Neck H, Brush C, Allen E (2009) The landscape of social entrepreneurship. Business Horizons 52: 13-19.

18. Nicholls A (2006) Playing the field: A new approach to the meaning of social entrepreneurship. Social Enterprise Journal 2: 1-5.

19. Nicholls A (2006) Social entrepreneurship, New models of sustainable social change. University Press, Oxford, New York, USA.

20. Zahra SA, Gedajlovic E, Neubaum DO, Shulman JM (2009) A typology of social entrepreneurs: Motives, search processes and ethical challenges. Journal of Business Venturing 24: 519-532.

21. Reber A S (1995) The Penguin Dictionary of Psychology. (2nd edn), Penguin Books, London.

22. Moreau Ch, Mertens S (2013) Managers' competences in social enterprises: Which specificities? Social Enterprise Journal 9: 164-183.

23. Nishantha B (2009) Influence of personality traits and socio-demographic background of undergraduate students on motivation for entrepreneurial career: The Case of Sri Lanka.

24. Meyskens M, Carsrud AL (2011) The role of partnerships on the legal structure and location choice of nascent social ventures. Journal of Enterprising Culture 19: 61-77.

25. Meyskens M, Carsrud AL, Cardozo R (2010) The impact of resources on the success of social entrepreneurship organizations: The symbiosis of entities in the social engagement network. Entrepreneurship \& Regional Development 22: 425-455.

26. Nicholls A (2010) The legitimacy of social entrepreneurship: Reflexive isomorphism in a pre-paradigmatic field. Entrepreneurship Theory and Practice 34: 611-633.

27. Short JC, Moss TW, Lumpkin GT (2009) Research in social entrepreneurship: Past contributions and future opportunities. Strategic Entrepreneurship Journal 3: 161194.

28. Burton BK, Goldsby M (2009) Corporate social responsibility orientation, goals, and behavior: A study of small business owners. Business \& Society 48: 88-104.

29. Schumpeter JA (1934) The theory of economic development: An inquiry into profits, capital, credit, interest, and the business cycle. Cambridge, Harvard University Press, MA, USA. 
30. Van Praag CM, Versloot PH (2007) What is the value of entrepreneurship? A review of recent research. Small Business Economics 29: 351-382.

31. Dacin PA, Dacin MT, Matear M (2010) Social entrepreneurship: Why we don't need a new theory and how we move forward from here. Academy of Management Perspectives.

32. Drayton W (2002) The citizen sector: Becoming as entrepreneurial and competitive as business. California Management Review 44: 120-132.

33. Kuratko DF, Hornsby JS, McMullen JS (2011) Corporate entrepreneurship with a purpose: Exploring the antecedents to social business. Academy of Management.

34. Boschee J (2001) The Social Enterprise Sourcebook. Edwards, New York, USA.

35. Defourny J, Nyssens M (2010) Conceptions of social enterprise and social entrepreneurship in Europe and the United States: Convergences and divergences. Journal of Social Entrepreneurship 1: 32-53.

36. Thompson J, Alvy G, Lees A(2000)Socialentrepreneurship-a new look at the people and the potential. Management Decision 38: 328-338.

37. Sullivan Mort Gillian, Weerawardena Jay, Carnegie Kashonia (2003) Social entrepreneurship: Towards conceptualisation. International Journal of Nonprofit and Voluntary Sector Marketing 8: 76-88.

38. Santos FM (2012) A positive theory of social entrepreneurship. Journal of Business Ethics 111: 335-351.

39. Guzmán A, Trujillo M (2008) Emprendimiento socialrevisión de literatura. Social Entrepreneurship-Literature Review 1. EstudiosGerenciales 24: 105-125.

40. Tracey P, Phillips N (2007) The distinctive challenge of educating social entrepreneurs: A postscript and rejoinder to the special issue on entrepreneurship education. Academy of Management Learning \& Education 6: 264-271.

41. Caliendo M, Fossen FM, Kritikos AS (2011) Personality characteristics and the decision to become and stay selfemployed. School of Business \& Economics Discussion Paper: Economics, No. 2011/9, Freie Universität.

42. Frank H, Lueger M, Korunka C (2007) The significance of personality in business start-up intentions, start-up realization and business success. Entrepreneurship and Regional Development 19: 227-251.

43. Schmidt MJ, Kinm JA, Robie C (2000) Development of a global measure of personality. Personnel Psychology 53: 153-193.

44. Prieto LC (2011) The influence of proactive personality on social entrepreneurial intentions among African-American and hispanic undergraduate students: The moderating role of hope. Academy of Entrepreneurship Journal 17: 7796.

45. Nga JKH, Shamuganathan G (2010) The influence of personality traits and demographic factors on social entrepreneurship start up intentions. Journal of Business Ethics 95: 259-282.

46. Izquierdo E, Buelens M (2008) Competing models of entrepreneurial intentions: The influence of entrepreneurial self-efficacy and attitudes. Paper presented at the Internationalizing Entrepreneurship Education and Training, Int Ent 2008 Conference, Oxford, USA.

47. Krueger NF Jr, Reilly MD, Carsrud AL (2000) Competing models of entrepreneurial intentions. Journal of Business
Venturing 15: 411-432.

48. Rauch A, Frese M (2007) Let's put the person back into entrepreneurship research: $A$ meta-analysis on the relationship between business owners' personality traits, business creation, and success. European Journal of Work and Organizational Psychology 16: 353-385.

49. Gartner WB (1985) A conceptual framework for describing the phenomenon of new venture creation. Academy of Management Review 10: 696-706.

50. Frese M, Gielnik MM (2014) The psychology of entrepreneurship. Annual Review of Organizational Psychology and Organizational Behaviour 1: 413-438.

51. American Psychiatric Association (2000) Diagnostic and statistical manual of mental disorders. ( $4^{\text {th }}$ edn).

52. Allport GW (1955) The Nature of Prejudice. Cambridge, Mass, Addison-Wesley, USA.

53. Burger JM (2006) Kişilik: Psikoloji BilimininInnsan Doğasına DairSöyledikleri, İstanbul: KaktüsYayınları.

54. Mount MK, Barrick MR, Scullen SM, Rounds J (2005) Higher-order dimensions of the big five personality traits and the big six vocational interest types. Personnel Psychology 58: $447-478$

55. Brandstätter H (2011) Personality aspects of entrepreneurship: A look at five meta-analyses. Personality and Individual Differences 51: 222-230.

56. Colin E Vize, Katherine L Collison, Joshua D Miller, Donald R Lynam, Mitja Back (2018) Examining the effects of controlling for shared variance among the dark triad using meta-analytic structural equation modelling. European Journal of Personality 32: 46-61.

57. Cromie S (2000) Assessing entrepreneurial inclinations: Some approaches and empirical evidence. European Journal of Work and Organizational Psychology 9: 7-30.

58. Bird BJ (1988) Implementing entrepreneurial ideas: The case for intention. Academy of Management Review 13: 442-453.

59. McClelland David C (1961) The achieving society. University of illinois at urbana-champaign's academy for entrepreneurial leadership historical research reference in entrepreneurship.

60. Brandstätter H (1997) Becoming an entrepreneur: A question of personality structure? Journal of Economic Psychology 18: 157-177.

61. Caliendo M, Kritikos A (2012) Searching for the entrepreneurial personality: New evidence and avenues for further research. Journal of Economic Psychology 33: 319-324.

62. Caliendo M, Fossen FM, Kritikos AS (2010) The impact of risk attitudes on entrepreneurial survival. Journal of Economic Behavior and Organization 76: 45-63.

63. Chell E (2008) The entrepreneurial personality: A social construction. In: Costa PT, McCrae RR (1992). (2 $2^{\text {nd }}$ edn), Revised NEO Personality Inventory, Routledge, London.

64. Gorman G, Dennis Hanlon, Wayne King (1997) Some research perspectives on entrepreneurship education, enterprise education and education for small business management: A ten-year literature review. International Small Business Journal 15: 56-79.

65. Kourilsky ML (1980) Predictors of entrepreneurship in a simulated economy. Journal of Creative Behavior 14: 175199. 
66. LiñánF, Chen YW(2006)Testing theentrepreneurialintention model on a two country sample. Barcelona: Departament d' Economia de l' Empresa, UniversitatAutònoma de Barcelona.

67. Robinson PB, Stimpson DV, Huefner JC, Hunt HK (1991) An attitude approach to the prediction of entrepreneurship. Entrepreneurship Theory and Practice 15: 13-30.

68. Wood MS (2009) Population level conditions as signals of entrepreneurial opportunities: A cognitve synthesis of the entrepreneurial traits and population rates perspectives. Ph.D. Dissertation, Southern Illinois University Carbondale.

69. Tan WL, Williams J, Tan TM (2005) Defining the 'social' in 'social entrepreneurship': Altruism and entrepreneurship. The International Entrepreneurship and Management Journal 1: 353-365.

70. Ashoka (2007) Everyone is a changemaker: Social entrepreneurship's ultimate goal. Arlington, USA, 1: 80-96.

71. Peredo Ana Maria, McLean Murdith (2006) Social entrepreneurship: A critical review of the concept. Journal of World Business 41: 56-65.

72. Goldberg LR (1993) An alternative "Description of Personality": The big five factor structure. Journal of Personality and Social Psychology 59: 1216-1229.

73. Zhao H, Seibert SE (2006) The big five personality dimensions and entrepreneurial status: A meta-analytical review. Journal of Applied Psychology 91: 259-271.

74. Zhao H, Seibert SE, Hills GE (2005) The mediating role of self-efficacy in the development of entrepreneurial intentions. J Appl Phycol 90: 1265-1272.

75. Leutner Franziska, AhmetogluGorkan, Akhtar Reece, Chamorro-Premuzic Tomas (2014) The relationship between the entrepreneurial personality and the big five personality traits. Personality and Individual Differences 63: 58-63.

76. Yap SCY, Anusic I, Lucas RE (2012) Does personality moderate reaction and adaptation to major life events? evidence from the british household panel survey. J Res Pers 46: 477-488.

77. Hussein SNA, Aziz HHA (2017) The big five personality dimensions as a predictor of entrepreneurial status in Egypt. International Journal of Entrepreneurship and Small Business, Inderscience Enterprises Ltd, 32: 423-443.

78. Simon M, Houghton SM, Aquino K (2000) Cognitive biases, risk perception and venture formation: How individuals decide to start companies. Journal of Business Venturing 15: 113-134.

79. Bajwa SU, Shahzad K, Aslam MH (2017) Exploring big-5 personality traits and gender as predictors of entrepreneurs' cognitive adaptability. Journal of Modelling in Management 12: $143-161$

80. Singh G, De Noble AF (2003) Views on self-employment and personality: An exploratory study. Journal of Developmental Entrepreneurship 8: 265-281.

81. Stewart WH, Roth PL (2004) Data quality affects metaanalytic conclusions: A response to Miner and Raju (2004) Concerning entrepreneurial risk propensity. J Appl Psychol 89: 14-21.

82. Wang JH, Liang C (2015) Empowerment through intrinsic motivation and self-efficacy: How personality traits influence rural practice in agricultural students? In: Hawkins $\mathrm{J}$, Personality traits and types: Perceptions, gender differences and impact on behavior. Hauppauge, Nova Science Publishers, NY, USA, 109-132.
83. Liang Chao-Tung, Chia Tsorng-Lin, Liang Chaoyun (2015) Effect of personality differences in shaping entrepreneurial intention. International Journal of Business and Social Science 6: 166-176.

84. Hans-Georg Wolff, Sowon Kim (2012) The relationship between networking behaviors and the big five personality dimensions. Career Development International 17: 43-66.

85. Zabelina DL, Robinson MD, Anicha CL (2007) The psychological tradeoffs of self-control: A multi-method investigation. Personality and Individual Differences 43: 463-473.

86. Van Der Molen HT, Schmidt HG, Kruisman G (2007) Personality characteristics of engineers. European Journal of Engineering Education 32: 495-501.

87. Denissen JJA, Penke L (2008) Motivational individual reaction norms underlying the five-factor model of personality: First steps towards a theory-based conceptual framework. Journal of Research in Personality 42: 1285-1302.

88. Baer RA, Smith GT, Hopkins J, Krietemeyer J, Toney L (2006) Using self-report assessment methods to explore facets of mindfulness. Assessment 13: 27-45.

89. Le H, Oh I-S, Robbins SB, Ilies R, Holland E, et al. (2011) Too much of a good thing: Curvilinear relationships between personality traits and job performance. J Appl Psychol 96: 113-133.

90. Penney LM, David E, Witt LA (2011) A review of personality and performance: Identifying boundaries, contingencies, and future research directions. Human Resource Management Review 21: 297-310.

91. Ciaverella MA, Buchholtz AK, Riordan CR, Gatewood RD, Garnett SS (2004) The big five and venture survival: Is there a linkage? Journal of Business Venturing 19: 465-483.

92. Rothman S, Coetzer EP (2003) The big five personality dimensions and job performance. SA Journal of Industrial Psychology 29: 68-74.

93. Buccholz RA, Rosenthal SB (2005) The spirit of entrepreneurship and the qualities of moral decision making: Toward a unifying framework. Journal of Business Ethics 60: 307-315.

94. Brenkert GG (2002) Entrepreneurship, Ethics and the Good Society. In: Freeman RE, Venkataraman S, Ruffin series in business ethics. Ethics and the Entrepreneur, 3: 5-43.

95. Buchanan JM, Di Pierro A (1980) Cognition, choice and entrepreneurship. Southern Economic Journal 46: 693-701.

96. Ariani DW (2013) Personality and learning motivation. European Journal of Business and Management 5: 26-38.

97. Drucker B (2014) Innovation and entrepreneurship. Taylor and Francis, Hoboken, New Jersey, USA.

98. Ilies R, Johnson MD, Judge TA, Keeney J (2011) A withinindividual study of interpersonal conflict as a work stressor: Dispositional and situational moderators. Journal of Organizational Behaviour 32: 44-64.

99. MacWilliams M (2016) The one weird trait that predicts whether you're a Trump supporter. Politico.

100. Jung CG (1971) Psychological types (Collected works of C. G. Jung), volume 6, Chapter X.

101. Sarasvathy SD (2001) Causation and effectuation: Toward a theoretical shift from economic inevitability to entrepreneurial contingency. The Academy of Management Review 26: 243263. 
102. Sarasvathy SD (2008) Effectuation: Elements of entrepreneurial expertise, New Horizons in entrepreneurship.

103. Alsos GA, Clausen TH (2014) The Start-up Processes of tourism firms: The use of causation and effectuation strategies. In: Alsos GA, Eide D, Madsen EL, Handbook of Research on Innovation in Tourism Industries, Edward Elgar, Cheltenham, UK, 181-202.

104. Dew N, Read S, Sarasvathy SD, Wiltbank R (2009) Effectual versus predictive logics in entrepreneurial decision-making: Differences between experts and novices. Journal of Business Venturing 24: 287-309.

105. Gabrielsson J, Politis D (2011) Career motives and entrepreneurial decision-making: Examining preferences for causal and effectual logics in the early stage of new ventures. Small Business Economics 36: 281-298.

106. Goel S, Karri R (2006) Entrepreneurs, effectual logic, and over-trust. Entrepreneurship Theory and Practice 30: 477493.

107. Harms R, Schiele H (2012) Antecedents and consequences of effectuation and causation in the international new venture creation process. Journal of International Entrepreneurship 10: $95-116$.
108. Kraaijenbrink J, Ratinho T, Groen A (2012) Planning the unknown: The simultaneity of predictive and nonpredictive entrepreneurial strategies. Paper Presented at Babson College Entrepreneurship Research Conference. Fort Worth, TX, USA, 6-9.

109. Perry JT, Chandler GN, Markova G (2012) Entrepreneurial effectuation: A review and suggestions for future research. Entrepreneurship Theory and Practice 36: 837-861.

110. Molino M, Dolce V, Cortese CG, Ghislieri C (2018) Personality and social support as determinants of entrepreneurial intention. Gender differences in Italy. PLOS ONE 13.

111. Bhave MP (1994) A process model of new venture creation. Journal of Business Venturing 9: 223-242.

112. Fernandes SF, Santos SC, Caetano A (2013) Prototypical dimensions of business opportunity in early stages of the entrepreneurial process. RevistaPsicologia: Organizações e Trabalho 13: 265-278.

113. Wagner J (2009) Are nascent entrepreneurs 'Jacks-of-alltrades'? A test of Lazear's theory of entrepreneurship with German data. Journal of Applied Economics 38: 2415-2419. 